I N S T I T U T O

DE

M E D I C I N A

T R O P I C A L

DE

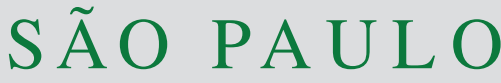

JOURNAL OF THE SÃO PAULO INSTITUTE OF TROPICAL MEDICINE

${ }^{1}$ Universidade Federal de Ouro Preto, Escola de Farmácia, Departamento de Análises Clínicas, Ouro Preto, Minas Gerais, Brazil

2Universidade Federal de Minas Gerais, Instituto de Ciências Biológicas, Belo Horizonte, Minas Gerais, Brazil

${ }^{3}$ Universidade Estadual do Maranhão, Campus de Lago da Pedra, Curso de Ciências Biológicas, Lago da Pedra, Maranhão, Brazil

${ }^{4}$ Prefeitura Municipal de Belo Horizonte, Belo Horizonte, Minas Gerais, Brasil.

${ }^{5}$ Prefeitura Municipal de Contagem, Contagem, Minas Gerais, Brazil

${ }^{6}$ Fundação Oswaldo Cruz, Programa de Computação Científica, Rio de Janeiro, Rio de Janeiro, Brazil

${ }^{7}$ Universidade Federal de Minas Gerais, Instituto de Ciências Exatas, Belo Horizonte, Minas Gerais, Brazil

Correspondence to: David Soeiro Barbosa Universidade Federal de Minas Gerais, Instituto de Ciências Biológicas, Av. Pres. Antônio Carlos, 6627, Pampulha, CEP 31270-901, Belo Horizonte, MG, Brazil

E-mail: davidsoeiro@gmail.com

Received: 07 October 2020

Accepted: 20 February 2021

\section{Spatiotemporal dynamics and risk estimates of COVID-19 epidemic in Minas Gerais State: analysis of an expanding process}

\author{
Wendel Coura-Vital ${ }^{\circledR 1}$, Diogo Tavares Cardoso ${ }^{\circledR 2}$, Fabricio Thomaz de \\ Oliveira Ker ${ }^{(1)}$, Fernanda do Carmo Magalhães ${ }^{(\mathbb{0} 2}$, Juliana Maria Trindade \\ Bezerra ${ }^{(1)}$, Ana Maria Viegas ${ }^{(1,5}$, Maria Helena Franco Morais ${ }^{(1,5}$, Leonardo \\ Soares Bastos ${ }^{(16}$, Ilka Afonso Reis ${ }^{(7}$, Mariângela Carneiro ${ }^{(1)}$, David Soeiro \\ Barbosa $^{(\mathbb{D}}$
}

\section{ABSTRACT}

COVID-19 is an infectious disease caused by the recently discovered coronavirus SARS-Cov-2. The disease became pandemic affecting many countries globally, including Brazil. Considering the expansion process and particularities during the initial stages of the epidemic, we aimed to analyze the spatial and spatiotemporal patterns of COVID-19 occurrence and to identify priority risk areas in Minas Gerais State, Southeast Brazil. An ecological study was performed considering all data from human cases of COVID-19 confirmed from the epidemiological week (EW) 11 (March 08, 2020) to EW 26 (June 27, 2020). Crude and smoothed incidence rates were used to analyze the distribution of disease patterns based on global and local indicators of spatial association and space-time risk assessment. Positive spatial autocorrelation and spatial dependence were found. Our results suggest that the metropolitan region of the State capital Belo Horizonte (MRBH) and Vale do Rio Doce mesoregions, as major epidemic foci in the beginning of the expansion process, have had important influence on the dispersion of SARS-CoV-2 in Minas Gerais State. Triangulo Mineiro/Alto Paranaiba region presented the highest risk of infection. In addition, six statistically significant spatiotemporal clusters were identified in the State, three at high risk and three at low risk. Our findings contribute to a greater understanding of the space-time disease dynamic and discuss strategies for identification of priority areas for COVID-19 surveillance and control.

KEYWORDS: COVID-19. Spatial analysis. Epidemiology. Minas Gerais.

\section{INTRODUCTION}

Since December 2019, when the new coronavirus SARS-CoV-2 emerged in Wuhan, China, humanity has faced a serious global health crisis ${ }^{1}$. New and numerous cases emerged quickly in Asian countries, such as Thailand, Japan, South Korea and Singapore, spreading to Europe and other continents, which led the World Health Organization (WHO) to enact it a Public Health Emergency of International Concern on January $30^{\text {th }}, 2020$, and a pandemic on March $11^{\text {th }}, 2020^{2}$. In Brazil, the first confirmed case was reported on February $26^{\text {th }}, 2020^{3}$, and, since then, the notification curve increased uninterruptedly, making the country one of the nations with the highest contagion rates ${ }^{4}$. One month later, on March 27th 3,417 cases had been confirmed in Brazil, 70\% of which were concentrated in nine cities: Sao Paulo, 
Rio de Janeiro, Fortaleza, Brasilia, Porto Alegre, Salvador, Curitiba, Manaus and Belo Horizonte ${ }^{5}$.

Estimates of March, 2020, regarding the most vulnerable areas for COVID-19 in Brazil, both in terms of risk of introduction and mortality associated with social vulnerability (according to human mobility statistics), had already pointed Belo Horizonte as one of the capitals that could be affected ${ }^{6}$. Nevertheless, the incidence rates in the capital of Minas Gerais were not as high as in Sao Paulo and Rio de Janeiro, as strict measures were adopted to control the spread of the virus, with the closure of local commercial establishments until the flexibilization process. Possibly due to this strict control, the incidence in the capital was not among the highest in the State during the period evaluated, but possibly influenced the spreading to other regions of Minas Gerais State. These interventions need to be described, discussed and could be useful during epidemic processes for governmental measures in similar contexts in Brazil.

According to data available on September $11^{\text {th }}, 2020$, the country was the third in the world with the highest number of confirmed cases of COVID-19, totaling $4,238,446$ cases and 129,522 deaths $^{7}$. Among the countries with a population of over one million inhabitants, Brazil appeared in the $7^{\text {th }}$ position in the epidemiological week (EW) 36, with a coefficient of 1.96 cases per 100,000 inhabitants. The highest incidence coefficients were observed in the North region (3.0 per 100,000 inhabitants) followed by the Midwest (2.8 per 100,000 inhabitants), Northeast (2.0 per 100,000 inhabitants), Southeast (1.6 per 100,000 inhabitants), and South (1.5 per $100,000$ inhabitants $)^{3}$.

In Minas Gerais State (MG) located in the Southeast region of Brazil, the first confirmed COVID-19 case occurred on March $9^{\text {th }}, 2020$, in the city of Divinopolis, being reported in a woman who had returned from Italy. By the end of April 2020, the COVID-19 epidemic was expanding with great geographical dispersion in Minas Gerais State, with many cases and deaths reported outside the capital ${ }^{8,9}$. Genomic data and epidemiological information of travelers returning to Minas Gerais allowed the identification of several independent viruses introductions in the State ${ }^{10}$. Thus, Minas Gerais has been identified, along with Sao Paulo and Rio de Janeiro, as one of the Brazilian States that received the greatest number of infected individuals returning from international travels ${ }^{11}$. The disease spread throughout the State and on September 11 $1^{\text {th }}, 2020$, it was present in 842 municipalities, corresponding to $98.7 \%$ of Minas Gerais municipalities. On this date, 246,149 cases and 6,114 deaths by COVID-19 had been confirmed in the State $^{12}$.
Considering the epidemiological profile of COVID-19, space-time studies are important to analyze variations in the aggregation and dispersion of the disease. In Brazil, some studies have evaluated the spatial dynamics of COVID-19 in States like Sao Paulo ${ }^{13,14}$, Pernambuco ${ }^{15}$, Sergipe $^{16}$ and Minas Gerais ${ }^{17-20}$. Thus, the main objective of this study is to analyze the spatial and temporal patterns of confirmed cases of COVID-19 in Minas Gerais, from March $8^{\text {th }}$ (EW 11) to June 27 $7^{\text {th }}$ (EW 26), 2020. A better understanding of the COVID-19 standards in Minas Gerais could provide strategic information for decision making directed to disease control.

\section{MATERIALS AND METHODS}

\section{Design and study area}

This is an ecological study that analyzed the spatial and temporal patterns of confirmed cases of COVID-19 from the EW 11 (March $8^{\text {th }}, 2020$ ) to EW 26 (June 27 $7^{\text {th }}, 2020$ ), reported by the State Health Secretariat of Minas Gerais (Secretaria Estadual de Saude de Minas Gerais - SES/MG). The units of analysis were all the 853 municipalities, which were analyzed considering their grouping in 12 mesoregions of Minas Gerais State.

Minas Gerais is one of the 27 federative units of Brazil, located in the Southeast region of the country. It has an area of 586,521.24 $\mathrm{km}^{2}$ and ranks fourth among the largest States in territorial extension. Minas Gerais is the second most populous State in Brazil, with an estimated population of 21.3 million inhabitants in 2020, and has the highest number of municipalities. These municipalities are grouped in 12 mesoregions: Campo das Vertentes; Central Mineira; Jequitinhonha; Metropolitan Region of Belo Horizonte (MRBH) (Regiao Metropolitana de Belo Horizonte); Northwest of Minas; North of Minas; West of Minas; South/Southwest of Minas; Triangulo Mineiro/Alto Paranaiba; Vale do Mucuri; Vale do Rio Doce; and Zona da Mata (Figure 1). The State capital is the municipality of Belo Horizonte, whose metropolitan region concentrates six million inhabitants ${ }^{21}$.

\section{Source and adjustment of data}

In this study, the analyzed data refer to the number of confirmed cases of COVID-19 notified by the municipalities and available in the SES/MG notification system. Aiming to correct misreports in the number of confirmed cases, SES/MG started inserting negative values for cases reported incorrectly in the municipalities (cases that were not confirmed by laboratory testlater ), but without identifying 

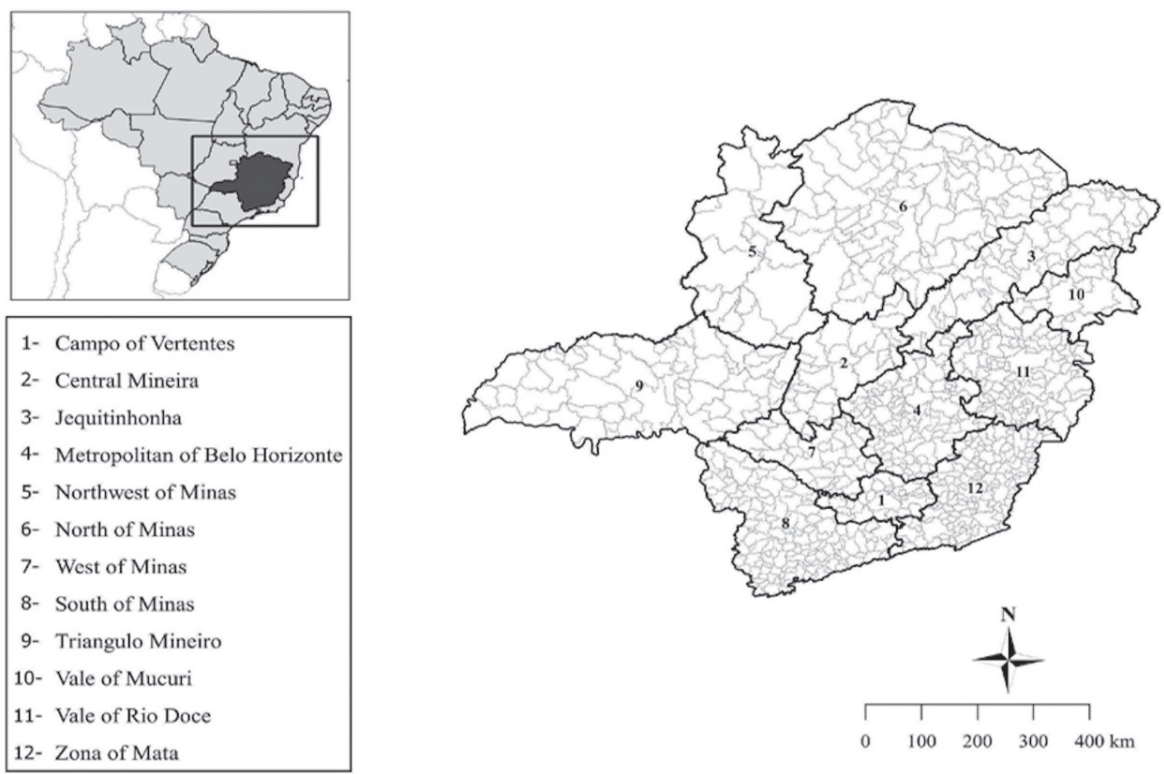

Figure 1 - Mesoregions and municipalities of Minas Gerais State, Brazil.

the date of the error. To adjust data for the analysis, negative records were subtracted from the historical series of the municipality. Most of the negative records referred to a few cases and were automatically removed. When the negative records were greater, the strategy adopted was to proportionally subtract them from the days with a greater number of cases, thus avoiding "breaks" in the epidemic curves.

\section{Incidence rates and spatial analyses}

Incidence rates were calculated aggregating periods of two weeks for all the municipalities of Minas Gerais. To calculate the incidence rates, each case was aggregated by the municipality of residence (analytical unit). The population estimates were set considering projections of the Federal Court of Audit (Tribunal de Contas da Uniao - TCU) calculated yearly for each municipality, based on data from the Brazilian Institute of Geography and Statistics (Instituto Brasileiro de Geografia e Estatistica - IBGE) ${ }^{22}$. The two-week time aggregation was chosen for the temporal and spatiotemporal analyzes because weekly data was too noisy, especially for small municipalities.

To estimate the spatial variability of area data, the spatial proximity matrix or neighborhood matrix was created. Given a set of $n$ areas $\left\{A_{1}, . ., A_{n}\right\}$, we construct the matrix $W^{(1)}(n \times n)$, in which each of the elements $w_{i j}$ represents a measure of proximity between $A_{i}$ and $A_{j}$. Data were smoothed using the empirical Bayes method, as an estimate correction for underreporting based on neighbors, and the two-week aggregation provided more robustness for the COVID-19 incidence data for the spatiotemporal analyses ${ }^{23}$.
The Directional Distribution Ellipse provides knowledge of the spatial distribution of events in two directions: cluster identification and orientation. The largest axis defines the direction of maximum dispersion of the distribution, while the smallest is perpendicular to the largest one and defines the minimum dispersion. This tool transforms the random spatial distribution of COVID-19 cases into an ellipse. Ellipses mark the areas with higher concentrations of cases and provide information about the asymmetry and spatial distribution of the cases ${ }^{24}$.

The Global Moran Index (Moran's I) was used to verify whether incidence rates in neighboring municipalities occurred at random and was calculated for each group of epidemiological weeks ${ }^{25}$. The index considers in its calculation the number of areas, the value of the attribute considered in the area, the average value of the attribute in the study region, and the elements of the neighborhood matrix. It was used to verify the occurrence of positive or negative spatial autocorrelation. In a second step, Local Indicators of Spatial Association (LISA) were used to identify purely spatial clusters. The Moran's Global index generates value for the entire study area, after the global Moran Index has been carried out by LISA. Unlike the Moran's Global index, LISA generates a value for each unit of analysis, so LISA breaks down the Moran's Global index, generating a value for each unit of analysis. In this way, each municipality was classified according to its position within the quadrants of the Moran dispersion graph as follows: Quadrant 1 (High-High) corresponding to the areas of highest priority; Quadrant 2 (Low-Low) corresponding to the areas of lowest priority; and Quadrant 3 (High-Low) and Quadrant 4 (Low-High) corresponding to areas of 
intermediate priority ${ }^{26}$. The clusters that presented a $\mathrm{p}$-value $\leq 0.05$ in the LISA test were considered statistically significant.

For the identification of high and low risk space-time clusters of COVID-19 the spatial scan statistical analyses were performed using the case data set, population, and location. To perform the tests, the following data were entered into the software for each municipality: (1) number of cases, (2) week of infection, (3) population average, and (4) geocode ${ }^{27}$. Space-time analyses were established using time standardized in days, adjusted for day-of-week data with the space-time scanning technique considering a Poisson probability distribution, with the following settings: non-occurrence of geographical overlapping of clusters, maximum spatial size of each cluster equal to $50 \%$, maximum temporal size of each clusters equal to $13 \%$ of the study period and the measurement of a minimum number of two cases and the level of significance set at $\mathrm{p} \leq 0.05$ using the SaTScan software (Version 9.4.4, SaTScan ${ }^{\mathrm{TM}}$, Boston, MA, USA). In order to compare the different in incidence rates of each municipality by means of Monte Carlo simulations, relative risk (RR) values of occurrence of COVID-19 were calculated for each cluster with regard to its neighboring locations. The RR value is calculated as the observed value divided by the expected one within the cluster, divided by the observed value that in turn is divided by the expected value outside the cluster.

The database was organized using Microsoft Excel version 2013. The tabulated database was merged with the spatial database from IBGE using the softwares ArcGis (Version 10.4, ESRI, Redlands, CA, USA) and GeoDa (Version 1.4, GeoDa Center, Arizona, USA). The resultant database was used for the elaboration of descriptive choropleth maps of the variables and the spatial analysis. To identify spatiotemporal clusters, the software (Version 9.4.4, SaTScan $^{\text {TM }}$, Boston, MA, USA) for scanning statistics was used.

\section{Ethical considerations}

This study used secondary data and all the information presented is available in public domains. Non-nominal, open access, aggregated data available in databases were obtained from the SES/MG. Nevertheless, this study was submitted to and approved by the Ethics Committee of the Federal University of Ouro Preto (CAAE 32267920.7.0000.515).

\section{RESULTS}

\section{Trend analysis}

Figure 2 shows the incidence rates for all mesoregions of Minas Gerais State between EWs 11/12 and 25/26 (larger plot). The smaller plot highlights the historical series between EWs 11/12 and 17/18, when incidence rates were lower. Between EWs 11 and 14, MRBH stood out with the highest incidence rates. From EW 15, the mesoregions West of Minas, South/Southwest of Minas, Triangulo Mineiro/Alto Paranaibaand Zona da Mata began to show incidence rates close to that observed in the MRBH and higher than that of Minas Gerais State. In EWs 17/18, the Vale do Mucuri mesoregion presented a high increment in its incidence rate. In EWs 19/20, the

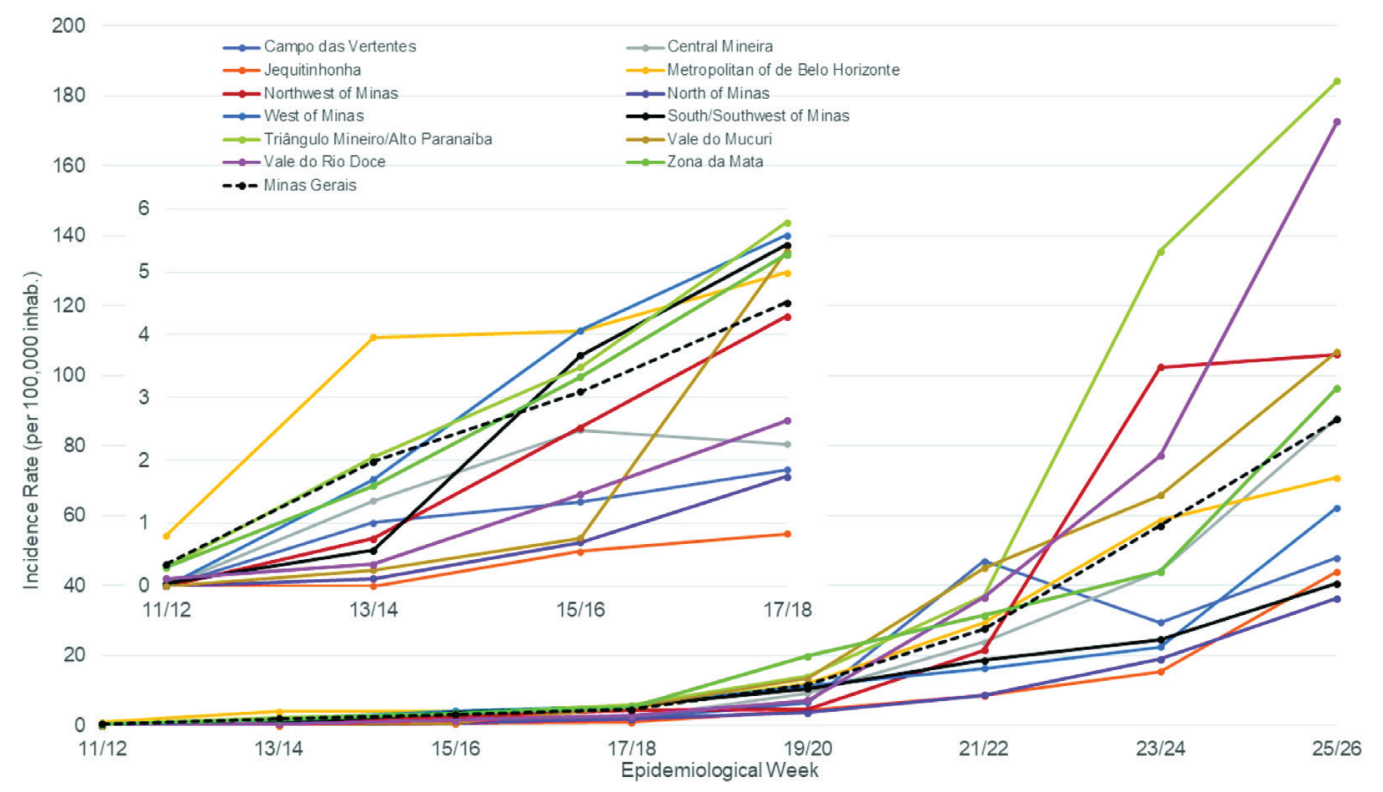

Figure 2 - COVID-19 time-series by mesoregions of Minas Gerais State, Brazil. 
incidence rate of Zona da Mata stood out and showed a gradual increase over the weeks, peaking in EWs 25/26. As of EWs 23/24, the mesoregion Triangulo Mineiro/ Alto Paranaiba stood out with the highest incidence rates, followed by Vale do Rio Doce, Northwest of Minas, Vale do Mucuri and Zona da Mata. MRBH showed an increase in its incidence rate up until EWs 23/24, when its curve reduced the slope. Campo das Vertentes showed a sudden increase in the incidence rate by EWs 21/22, which was followed by a decrease.

Almost all mesoregions showed a continuous increase in their incidence coefficients, some of which were more accelerated. The mesoregions North of Minas and Jequitinhonha remained with the lowest incidence rates throughout the evaluated period.

\section{Spatial analysis}

\section{Incidence patterns}

In EWs 11/12, confirmed cases occurred in cities of the mesoregions Triangulo Mineiro (Patrocinio, Uberaba, and Uberlandia), South/Southwest of Minas (Pocos de Caldas), West of Minas (Divinopolis), MRBH (Belo Horizonte, Contagem, Betim, Sete Lagoas, and Mariana), Vale do Rio Doce (Ipatinga, Timoteo, and Coronel Fabriciano), and Zona da Mata (Juiz de Fora) (Figure 3).

As of EWs 13/14, the disease expanded to the Northwest of Minas (Vazante, Paracatu, and Unai), Campo das Vertentes (Barbacena, Lavras, and Sao Joao Del Rey), Central Mineira (Bom Despacho), North of Minas (Janauba and Montes Claros) and Vale do Mucuri (Nanuque) (Figure 3).
EWs $11 / 12$

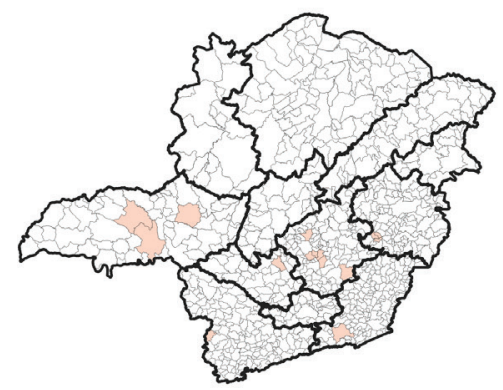

EWs $17 / 18$

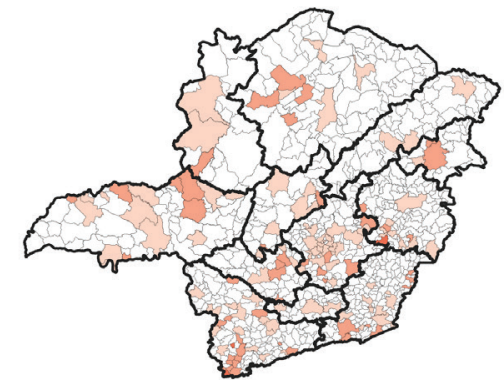

EWs 23/24

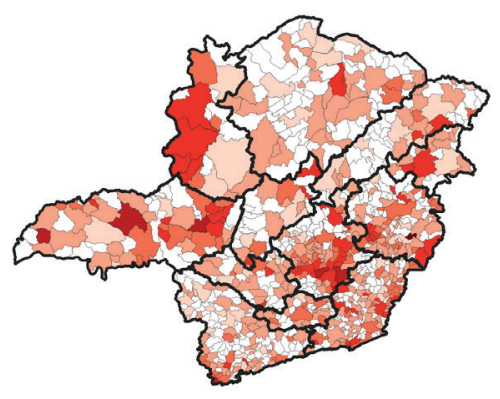

EWs $13 / 14$

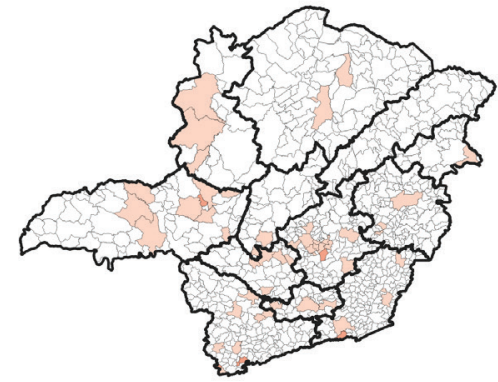

EWs $19 / 20$

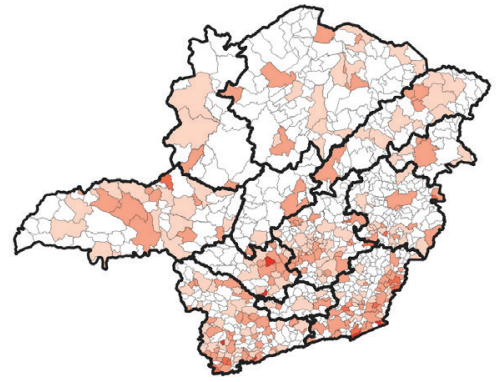

EWs $25 / 26$
EWs $15 / 16$

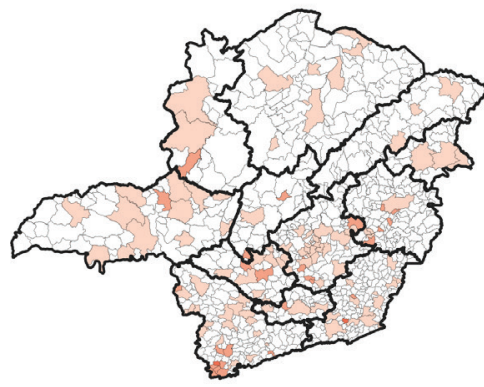

EWs $21 / 22$
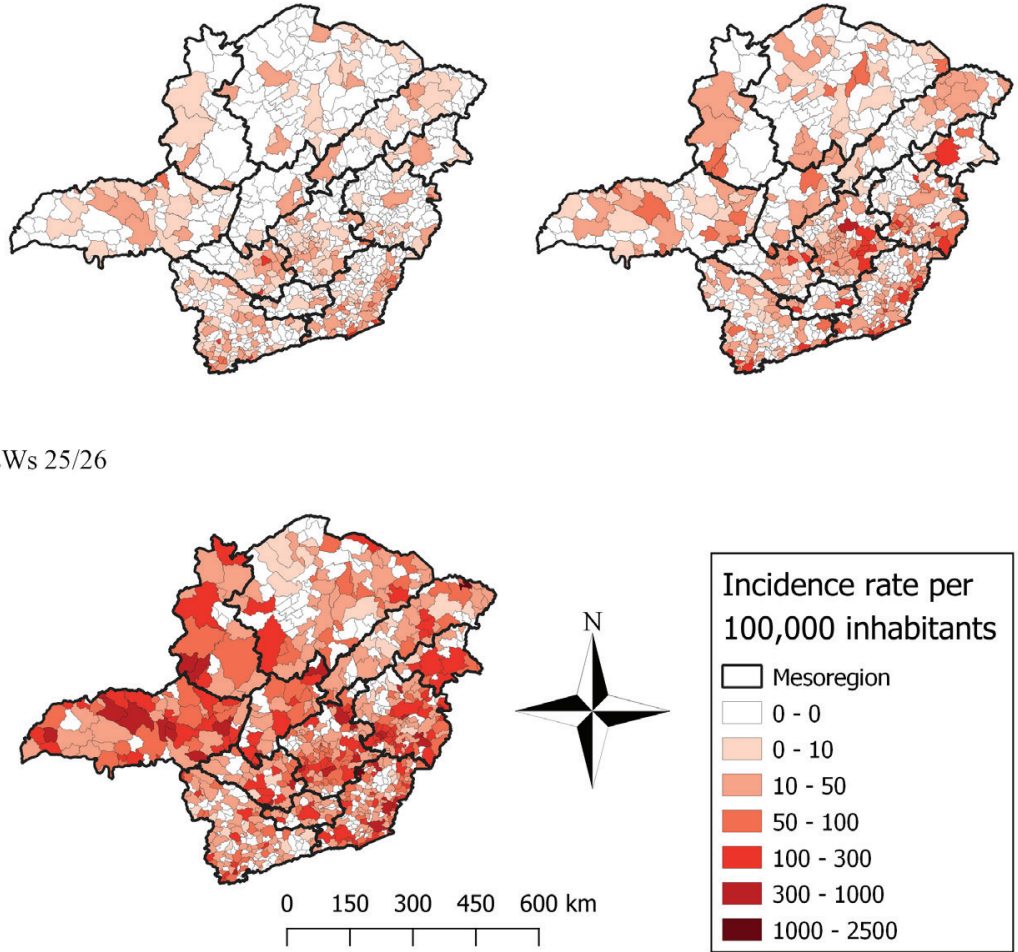

Figure 3 - Spatial distribution of the incidence rates of COVID-19 in cities of the mesoregions of Minas Gerais State, Brazil. 
By the EWs 15/16, all mesoregions of the State had registered confirmed cases of COVID-19, with Jequitinhonha being the last mesoregion to notify cases. It was observed that in EWs 23/24 all mesoregions, except for Campo das Vertentes, had municipalities with an incidence rate higher than 100 per 100,000 inhabitants (Figure 3).

\section{Spatial clusters and spreading}

Table 1 presents Moran's I for the incidence rates of confirmed cases of COVID-19 for each group of EWs in Minas Gerais State. During all the studied time periods, the global spatial autocorrelation was statistically non-null $(\mathrm{p}<0.01)$ but presented a weak magnitude.

When analyzing the local spatial autocorrelation and the directional distribution ellipse (Figure 4), it is possible to observe clustering patterns and spreading of COVID-19 epidemic foci in the municipalities of Minas Gerais over the EWs. The LISA showed how the groups of municipalities classified as High-High, which were in a more critical situation regarding the incidence of COVID-19, were dispersed throughout the State over time. This dispersion occurred from the mesoregions MRBH and Vale do Rio Doce, which had municipalities classified as High-High in the first fortnight (EWs 11/12). In EWs 13/14, the ellipse expanded as the number of municipalities classified as High-High increased through the State, being observed in the mesoregions of the Triangulo Mineiro/Alto Paranaiba, South/Southwest of Minas, West of Minas, Central Mineira, Zona da Mata, and MRBH. In EWs 15/16, the ellipse shifted to the mesoregion South/Southwest of Minas. In the following weeks and until EWs 21/22, it expanded again, with municipalities classified as High-High in the West of Minas, MRBH, Zona da Mata, South/Southwest of Minas and Vale do Rio Doce.

In EWs 23/24, the mesoregions Northwest of Minas and Triangulo Mineiro/Alto Paranaiba have also presented groups of municipalities classified as High-High by LISA. In EWs 25/26, groups of municipalities classified as HighHigh were observed in seven mesoregions: MRBH, Vale do Rio Doce, Zona da Mata, Triangulo Mineiro/Alto Paranaiba, Northwest of Minas, Central Mineira and Jequitinhonha. The North of Minas and Campos das Vertentes did not present municipalities classified as High-High until EW 26, despite the groups of municipalities classified as HighHigh in the mesoregions neighboring Campos das Vertentes (Figure 4).

The mesoregion Triangulo Mineiro/Alto Paranaiba recorded high incidences, mainly in EWs 23/24 and $25 / 26$, which contributed to the emergence of groups of municipalities with High-High and High-Low classifications. Despite registering an increase in incidence and remaining among the mesoregions with the highest incidence rates over EWs 17/18 and 21/22, this mesoregion did not present High-High groupings during this period, which may be attributed to the much larger explosion of cases in the South/Southeast of Minas, Vale do Mucuri, Zona da Mata, Campo das Vertentes and Vale do Rio Doce. This is because the threshold used in the LISA classification varied among the fortnightly intervals analyzed (Figure 4).

The Vale do Rio Doce mesoregion cluster, more specifically located in the Vale do Aco, had three HighHigh municipalities in EWs 11/12, maintained at least one municipality with High-High or High-Low classification until EWs 17/18, registered no significance in the EWs $19 / 20$, and resumed growth in the EWs $25 / 26$, when it reached nine municipalities classified as High-High. The MRBH cluster registered growth in the first two weeks, disappeared in EWs 15/16, returned in EWs 17/18, decreased again in EWs 19/20, and, since then, has shown continuous growth, reaching neighboring regions located to the South (Figure 4).

Table 1 - Global Moran Index (Moran's I) to determine the incidence rates and clusters of confirmed cases of COVID-19 in each group of epidemiological weeks (EWs), in Minas Gerais State, Brazil.

\begin{tabular}{ccccc}
\hline Week & Moran's I & $p$ & Cluster number & $\begin{array}{c}\text { Number of municipalities } \\
\text { High-High }\end{array}$ \\
\hline EWs 11/12 & 0.0045 & $<0.01$ & 2 & 6 \\
EWs 13/14 & 0.075 & $<0.01$ & 2 & 13 \\
EWs 15/16 & 0.198 & $<0.01$ & 1 & 10 \\
EWs 17/18 & 0.107 & $<0.01$ & 3 & 16 \\
EWs 19/20 & 0.144 & $<0.01$ & 4 & 31 \\
EWs 21/22 & 0.116 & $<0.01$ & 4 & 35 \\
EWs 23/24 & 0.107 & $<0.01$ & 4 & 38 \\
EWs 25/26 & 0.155 & $<0.01$ & 3 & 39 \\
\hline
\end{tabular}

EWs $=$ epidemiological weeks; $p=p$-value 
EWs 11/12

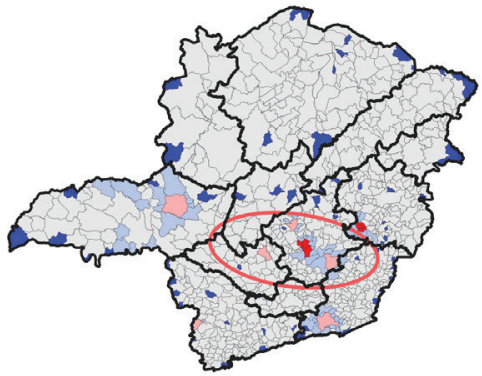

EWs $17 / 18$

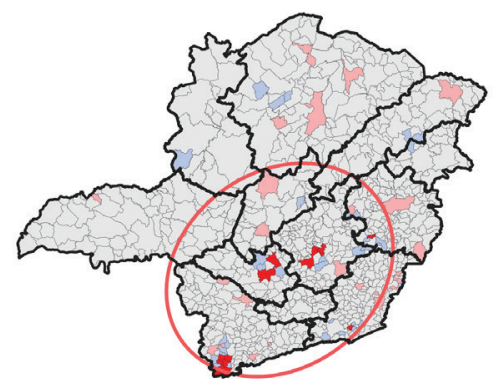

EWs 23/24

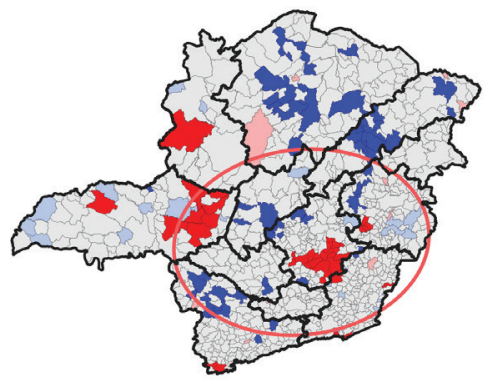

EWs $13 / 14$

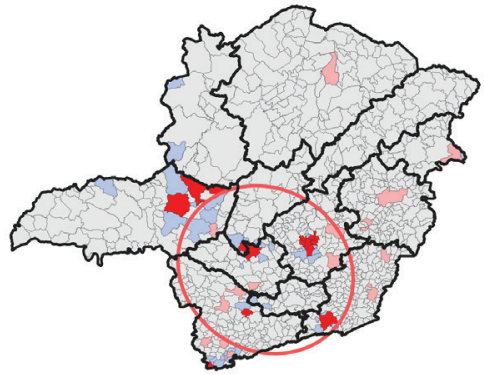

EWs $19 / 20$

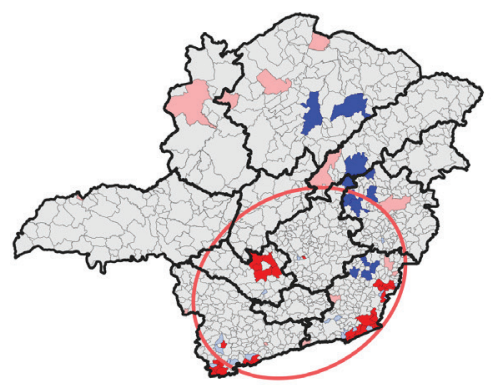

EWs 21/22

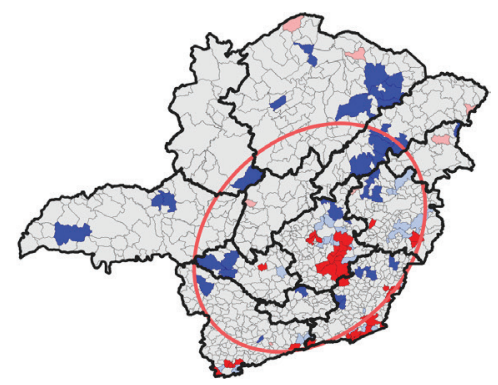

EWs $25 / 26$

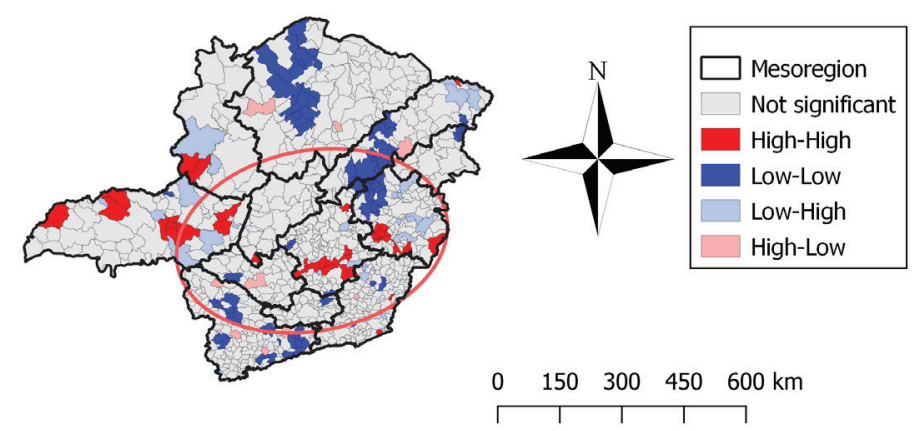

Figure 4 - Spatial clusters and directional distribution of COVID-19 (LISA clusters and directional ellipses) in the mesoregions cities of Minas Gerais State, Brazil.

\section{Space-time risk}

Six statistically significant space-time clusters were identified, three of which were of high risk and three of low risk. Among the high-risk groupings, cluster 1, located in Zona da Mata, Vale do Rio Doce and MRBH, had the longest duration (33 days), starting on May $25^{\text {th }}, 2020$, and remaining until the end of the analysis on June $27^{\text {th }}, 2020$ [relative risk $(\mathrm{RR})=5.54]$. In MRBH, group 2 , which included the capital Belo Horizonte, presented RR of 3.36 and lasted 23 days, from June $1^{\text {st }}$ to June $24^{\text {th }}, 2020$. Despite the two high-risk clusters, MRBH presented a low-risk cluster (cluster 5) with a RR of 0.04. This cluster lasted 57 days from March $3^{\text {rd }}$ to April $30^{\text {th }}, 2020$, and occurred in a period different from the high-risk clusters. The highest risk cluster occurred in the Triangulo Mineiro/Alto Paranaiba mesoregion (cluster 3) with a RR of 16.21 between May $29^{\text {th }}$ and June $27^{\text {th }}, 2020$ (Figure 5).

In addition to the low-risk cluster in MRBH, two lowrisk clusters $(R R=0.06)$ were detected between March $4^{\text {th }}$ and April $30^{\text {th }}, 2020$, and between March $5^{\text {th }}$ and May $1^{\text {st }}$, 2020 , coinciding with the occurrence of the low-risk cluster in MRBH (Figure 5).

\section{DISCUSSION}

In this study, we analyzed spatiotemporal patterns, highlighting priority areas and showing their relationships with the displacement of COVID-19 epidemic outbreaks in Minas Gerais State. SARS-CoV-2 has a contagion process 


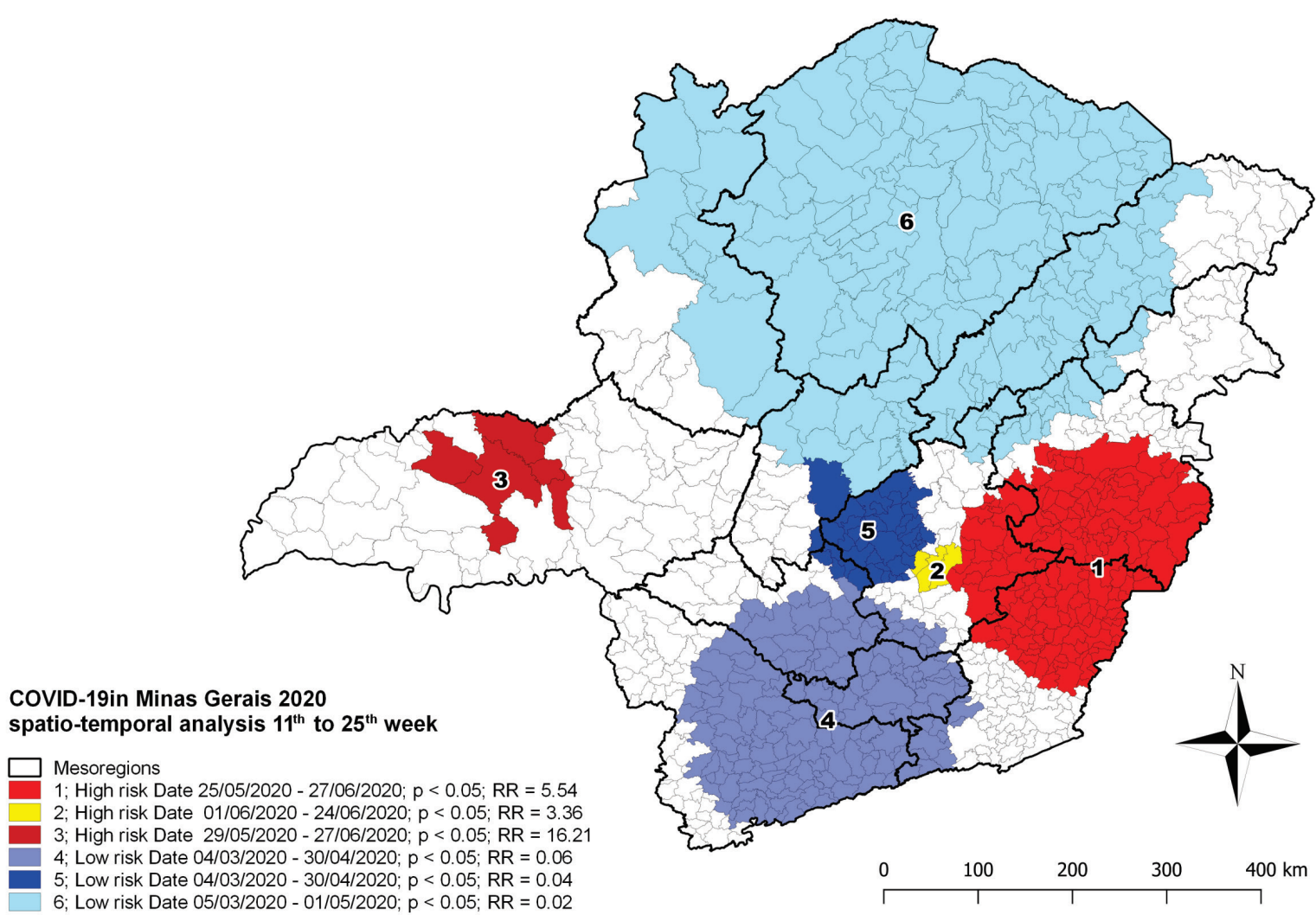

Figure 5 - Space-time groups of COVID-19 in the mesoregions cities of Minas Gerais State, Brazil. Sectors in red represent areas of high risk and sectors in blue represent areas of low risk.

similar to the influenza virus that has been addressed in previous studies of spatial analysis ${ }^{28,29}$. For this reason, the use of geoprocessing in the surveillance and control of COVID-19 offers a potential resource for planning and evaluating actions in this area. By means of these resources, it is possible to map, monitorand disseminate data about COVID-19 in a territory, therefore allowing the outlining of scenarios and better-targeted actions ${ }^{30}$.

The findings demonstrated that mesoregion MRBH was the one that has most influenced the expansion of COVID-19 in the State, with the highest incidence rates until EWs 15/16. From this moment on, all mesoregions of the State had confirmed cases, with Jequitinhonha being the last mesoregion to notify cases. As of EWs 17/18, testing for COVID-19 was expanded with the inclusion of serological tests in the State, which explains the increase in the number of confirmed cases. By EWs 19/20, there was an expressive increase in the number of cases of the disease, reaching almost all the mesoregions of the State, most markedly Triangulo Mineiro/Alto Paranaiba and Vale do Rio Doce. In Campo das Vertentes mesoregion, a peak incidence was observed in EWs 21/22, likely related to an outbreak of COVID-19 in a Brazilian air force school located in the municipality of Barbacena, which had not interrupted its academic activities. In EWs 24/25, a greater slope in the incidence curves was observed in almost all mesoregions, possibly due to the expansion of criteria to indicate serological tests, including people with comorbidities, the economically active population and suspected deaths from COVID-19 in the testing group ${ }^{31}$.

Additionally, the clusters of municipalities classified as High-High in the first two fortnights (EWs 11 to 14) were located in MRBH, Triangulo Mineiro/Alto Paranaiba, South/Southwest of Minas, Central Mineira, West of Minas and Zona da Mata. By EWs 25 and 26, eight mesoregions had municipalities classified as High-High. There was also a dynamic spread of the disease to the interior of the State, with expansion, retractionand movement of clusters. In addition, six statistically significant space-time clusters were identified, three of which were of high risk and three of low risk. Another study demonstrated that the first cases occurred in cities with the largest populations and greater connectivity with metropolitan areas and mediumsized cities, indicating a possible correlation between the hierarchy of cities in the urban network and the spread of the virus ${ }^{17}$.

A study that investigated the probable scenario for the dissemination of COVID-19 in Brazil through the analysis of the airport network showed the importance of the international airport of Belo Horizonte in the introduction of 
the virus in the State and its potential for the dissemination throughout the country ${ }^{32}$. This corroborates the fact that Minas Gerais received many infected individuals returning from international travels. In addition, genetic sequencing evidenced multiple strains of SARS-CoV-2 in Minas Gerais $^{10}$. A challenge to investigate the epidemic spread of SARS-CoV-2 in Minas Gerais was its low capacity to carry out diagnostic tests in the population, preventing a real understanding of its spread since its introduction ${ }^{33}$.

Nevertheless, the incidence rates in the capital of Minas Gerais were not as high as in Sao Paulo and Rio de Janeiro, as strict measures were adopted to control the spread of the virus, with the closure of local commercial establishments between March $20^{\text {th }}$ and August 12 ${ }^{\text {th }}, 2020$, when the flexibilization process was resumed. The first flexibilization process started on May $25^{\text {th }}, 2020$ and June $8^{\text {th }}, 2020$. However, on July $29^{\text {th }}, 2020$, the commercial establishments were closed again, and only those considered essential remained in operation. Possibly due to this strict control, the incidence in the capital was not among the highest in the State during the evaluated period.

In the South/Southwest of Minas, some municipalities classified as High-High in the EWs 15/16 to 23/24 were located close to the border of Sao Paulo State, which suggests the possible expansion of viral circulation from that State to Minas Gerais. A possible route for the spread of the virus is the BR-381 highway, which connects Sao Paulo to Belo Horizonte. In addition, a study considering reported cases from Minas Gerais evidenced relationships between the number of COVID-19 cases and the urban network, with emphasis on the level of centrality and the connections between urban centers, including, for example, the interconnected transportation infrastructure ${ }^{31}$.

Triangulo Mineiro/Alto Paranaiba is also influenced by Sao Paulo State, since this mesoregion has also a highway with great circulation that connects the States of Sao Paulo, Goias and the Federal District (BR-050). Rio de Janeiro State has possibly influenced the incidence rates of Zona da Mata, mainly in through the municipality of Juiz de Fora, which was the first to report cases in this mesoregion, contributing to the spread of the disease in the region. In addition, it is worth highlighting the influence of BR-040 that connects the municipalities of Rio de Janeiro and Belo Horizonte, crossing Juiz de Fora and several other cities of Zona da Mata. The highways have possibly interfered in the expansion of the disease across the State, since the increase in the number of cases in each municipality is mainly due to intra-urban transmissions. In a study that evaluated the relationship between the urban network and COVID-19 in Minas Gerais, the authors demonstrated that most cities are linked to Belo Horizonte, the State capital, which plays the role of a metropolis. However, other municipalities are integrated with other metropolises or, in some cases, share the area of influence with Belo Horizonte. The influence of the capital of Sao Paulo State in Triangulo Mineiro/ Alto Paranaiba and South/Southwest of Minas, of Rio de Janeiro State capital in Zona da Mata, and of Brasilia in the Northwest of the State is highlighted ${ }^{20}$.

Despite the continuous growth of incidence coefficients in the mesoregions, retraction and movement of clusters were also observed, indicating a dynamism in the dispersion of the disease to the interior of the State. The presence of High-High clusters in a given fortnight indicated an explosion of cases in a regional pole and dispersion to smaller neighboring municipalities. However, this did not mean that the other regions did not register growth. The increase and reduction of clusters at different times and in different locations can be directly related to the easing of social isolation ${ }^{34,35}$. Many clusters start small and grow, requiring mitigation measures that are usually stricter ${ }^{36}$. Nevertheless, if the measures are loosened, the cluster will be identified again shortly after.

The spatial dispersion of SARS-CoV-2 to the interior of Minas Gerais State possibly obeyed the following chain: (i) the virus entered a pole city, which led to the adoption of mitigation measures and the consequent decrease of viral circulation in that location; (ii) after a period, when the inhabitants of the pole city resumed part of the activities, the virus started to spread to first-order neighbors (those that surround the borders of the pole city); (iii) the first-order neighbors and the pole city began or resumed mitigation measures and the spread of the virus was consequently reduced; (iv) the population of the pole city and first-order neighbors resumed activities, and second and third-order neighbors (those that surround the borders of first-order neighbors) showed cases of the disease; (v) mitigating measures started again and activities were later resumed and so on. This behavior in the spatial distribution of COVID-19 cases in Minas Gerais State suggests that each step of loosening mitigation measures may have influenced the spread and internalization of the virus ${ }^{37,38}$. Noteworthy, at the beginning of the viral spread in the State, the internalization of the cases occurred not only from the capital, but also from pole cities such as Divinopolis, Juiz de Fora, Ipatinga and Uberlandia, which may have served as starting points for the spread of the infection to neighboring cities and mesoregions, mainly by roads/highways.

During the study period, six statistically significant spatiotemporal clusters were identified, three of which were of high risk and three of low risk. Through this spatial scanning, it was possible to determine the risk of falling ill in this region when compared to other regions. Among the high- 
risk groups, the one located in Zona da Mata, Vale do Rio Doce and MRBH had the longest period (33 days), remaining at high risk $(R R=5.54)$ from May $25^{\text {th }}$ to June $27^{\text {th }}, 2020$. Many municipalities located in this region have the extraction of iron ore as their main economic activity, constituting an important area called the iron quadrilateral. The iron quadrilateral is the largest national producer of iron ore, concentrating a large portion of the mining workforce, which remains active. Due to the periodic testing for COVID-19 carried out by mine owners on their employees, there was a considerable increase in the number of notifications in this region, thus explaining this greater risk ${ }^{39}$.

In MRBH, there was also a cluster with an RR of 3.36 (cluster 2), which lasted 23 days (from June $1^{\text {st }}$ to June $24^{\text {th }}, 2020$ ) and encompassed the city of Belo Horizonte. This lower RR among high-risk regions was possibly due to the previously mentioned mitigation measures adopted in the State capital. Cluster 3, identified in the mesoregion Triangulo Mineiro/Alto Paranaiba, presented the highest $R R$ of the entire analyzed period $(R R=16.21)$ and lasted between May $29^{\text {th }}$ and June $27^{\text {th }}$, 2020. This relative high risk has been strongly influenced by the city of Uberlandia, which presented, until the last day evaluated in this study, a greater number of cases $(5,889)$ than the State capital $(4,869)$, although its population corresponds to only $27.5 \%$ of that estimated for Belo Horizonte by the IBGE ${ }^{12,21}$. These high incidences in Uberlandia, in comparison to Belo Horizonte, are likely due to less severe measures of social isolation imposed by the local public sector. A geographic study on active spatiotemporal clusters of COVID-19 conducted from February $25^{\text {th }}$ to June $7^{\text {th }}, 2020$ in 5,570 Brazilian municipalities showed that one of the clusters was located in the Southeast region of Brazil covering the States of Minas Gerais, Espirito Santo and Rio de Janeiro. This cluster included 274 municipalities, 48 of which presented RR greater than $1.0^{40}$.

The availability of secondary data based on the mandatory notification of cases in an established surveillance system allows the comparison of areas at different levels of stratification. However, our results have some limitations. The underreporting of cases must be considered, in addition to the delay in notification by the municipalities. To minimize these limitations, our analyses considered spatiotemporal patterns with estimates from neighboring municipalities that can help to reduce the possible impact of data underreporting. The modifications made by the SES/MG to correct data in a given EW led us to adopt the strategy of removing notifications from previous weeks. However, a few cases were corrected by the municipality, but we believe that they did not compromise the results of our analyses.

\section{CONCLUSIONS}

The spatial dispersion of COVID-19 in Minas Gerais State occurred from the mesoregions MRBH and Vale do Rio Doce, which had municipalities classified as High-High in the first fortnight (EWs 11/12). MRBH was the mesoregion that has most influenced the expansion of SARS-CoV-2 transmission, despite the highest risk of infection observed in the Triangulo Mineiro/Alto Paranaiba. In addition, six statistically significant spatiotemporal groups were identified in the State, three of which were of high risk and three of low risk. It was noted that the social isolation measures adopted since the beginning of the pandemic helped to delay the emergence of new confirmed cases in some periods of the analysis. This reinforces the importance of adopting social distancing measures to mitigate local transmission in cities of Minas Gerais. Our findings contribute to a greater understanding of COVID-19 spatiotemporal dynamics and enable competent authorities to efficiently target priority areas for the disease in Minas Gerais State.

\section{REFERENCES}

1. Huang C, Wang Y, Li X, Ren L, Zhao J, Hu Y, et al. Clinical features of patients infected with 2019 novel coronavirus in Wuhan, China. Lancet. 2020;395:497-506.

2. World Health Organization. Coronavirus disease (COVID-19) pandemic. [cited $2021 \mathrm{Feb} 20$ ]. Available from: https://www. who.int/emergencies/diseases/novel-coronavirus-2019?gclid =EAIaIQobChMI3KuT5urh6wIVDAyRCh321QguEAAYAS AAEgKzYvD_BwE

3. Brasil. Ministério da Saúde. Secretaria de Vigilância em Saúde. Infecção humana PELO novo coronavírus (2019-nCoV). Bol Epidemiol. 2020;1:1-17. [cited 2021 Feb 20]. Available from: https://portalarquivos2.saude.gov.br/images/pdf/2020/ janeiro/28/Boletim-epidemiologico-SVS-28jan20.pdf

4. Bathia S, Cori A, Parag KV, Mishra S, Cooper LV, Ainslie KE, et al. Short-term forecasts of COVID-19 deaths in mulltiple coutries. London: Imperial College; 2020. [cited 2021 Feb 20]. Available from: https://mrc-ide.github.io/covid19-short-termforecasts/

5. Castro MC, Carvalho LR, Chin T, Kahn R, França GV, Macario EM, et al. Demand for hospitalization services for COVID-19 patients in Brazil. MedRxiv. In Press 2020. [cited 2021 Feb 20]. Available from: https://www.medrxiv.org/content/10.110 1/2020.03.30.20047662v1

6. Coelho FC, Lana RM, Cruz OG, Villela D, Bastos LS, Pastore y Piontti A, et al. Assessing the potential impact of COVID-19 in Brazil: mobility, morbidity and the burden on the Health Care System. MedRxiv. In Press 2020. [cited 2021 Feb 20] 
Available from: https://www.medrxiv.org/content/10.1101/2 020.03.19.20039131v2

7. Brasil. Ministério da Saúde. COVID 19: painel coronavírus. [cited 2021 Feb 20]. Available from: https://covid.saude.gov.br/

8. Minas Gerais. Secretaria de Estado de Saúde. Subsecretaria de Vigilância em Saúde. Informe epidemiológico 02: Centro de Operações de Emergência em Saúde Pública - COES COVID 19. [cited 2021 Feb 20]. Available from: http://coronavirus. saude.mg.gov.br/images/boletim/03-marco/02032020_ Boletim_epidemiologico_COVID-19_MG.pdf

9. Minas Gerais. Secretaria de Estado de Saúde. Boletim informativo diário: data 09/03/2020, hora 15:08: Centro de Operações de Emergência em Saúde Pública - Coes Minas COVID-19. [cited $2021 \mathrm{Feb} 20$ ]. Available from: http://coronavirus.saude. mg.gov.br/images/boletim/03-marco/09032020_Boletim epidemiologico_COVID-19_MG.pdf

10. Xavier J, Giovanetti M, Adelino T, Fonseca V, Costa AV, Ribeiro AA, et al. The ongoing COVID-19 epidemic in Minas Gerais, Brazil: insights from epidemiological data 2 and SARSCoV-2 whole genome sequencing. Emerg Microbes Infect. 2020;9:1824-34.

11. Candido DS, Claro IM, de Jesus JG, Souza WM, Moreira FR, Dellicour S, et al. Evolution and epidemic spread of SARSCoV-2 in Brazil. Science. 2020;369:1255-60.

12. Minas Gerais. Secretaria de Estado de Saúde. Boletim epidemiológico: COVID-19: doença causada pelo coronavírus-19: 11 de setembro de 2020. [cited 2021 Feb 20]. Available from: http://coronavirus.saude.mg.gov.br/images/ Boletim-Epidemiologico_COVID-19_11.09.2020.pdf

13. Bermudi PM, Lorenz C, Aguiar BS, Failla MA, Barrozo LV, Chiaravalloti-Neto F. Spatiotemporal ecological study of COVID-19 mortality in the city of São Paulo, Brazil: shifting of the high mortality risk from areas with the best to those with the worst socio-economic conditions. Travel Med Infect Dis 2020;39:101945

14. Rex FE, Borges CA, Käfer PS. Spatial analysis of the COVID-19 distribution pattern in São Paulo State, Brazil. Cien Saude Colet. 2020;25:3377-84.

15. Souza WV, Martelli CM, Silva AP, Maia LT, Braga MC, Bezerra LC, et al. The first hundred days of COVID-19 in Pernambuco State, Brazil: epidemiology in historical context. Cad Saude Publica. 2020;36:e0228220.

16. Andrade LA, Gomes DS, Góes MA, Souza MS, Teixeira DC Ribeiro CJ, et al. Surveillance of the first cases of COVID-19 in Sergipe using a prospective spatiotemporal analysis: the spatial dispersion and its public health implications. Rev Soc Bras Med Trop. 2020;53:e20200287.

17. Ferreira RV, Carvalho DM, Souza AL, Martines MR, Assunção LM. COVID-19 na região de saúde Triângulo Sul, MG: uma perspectiva cartográfica. Hygeia. 2020;Ed Esp COVID-19:49-59.
18. Teixeira SH, Souza AL. Análise da distribuição geográfica de COVID-19 na Mesorregião Sul/Sudoeste de Minas Gerais. Hygeia, 2020;Ed Esp COVID-19:407-16.

19. Carvalho PF, Pardini H. Análise da distribuição espacial da COVID-19 em Minas Gerais. Metodol Aprendizado. 2020;2:159-66.

20. Batella W, Miyazaki V. Relações entre rede urbana e COVID-19 em Minas Gerais. Hygeia. 2020;Ed Esp COVID-19:102-10.

21. Instituto Brasileiro de Geografia e Estatística. Cidades e estados: Minas Gerais. [cited 2021 Feb 20]. Available from: https:// www.ibge.gov.br/cidades-e-estados/mg.html

22. Instituto Brasileiro de Geografia e Estatística. Estimativas da população. [cited $2021 \mathrm{Feb} 20$ ]. Available from: https://www. ibge.gov.br/estatisticas/sociais/populacao/9103-estimativasde-populacao.html?=\&t=resultados

23. Druck S, Carvalho MS, Câmara G, Monteiro AM, editores. Análise espacial de dados geográficos. Brasília: Embrapa; 2004.

24. Yuill RS. The standard deviational ellipse: an updated tool for spatial description. Geogr Ann Ser B. 1971;53:28-39.

25. Moran PA. The interpretation of statistical maps. J R Stat Soc. 1948;10:243-51.

26. Anselin L. Local indicator of spatial association - LISA. Geogr Anal. 1995;27:93-115.

27. Kulldorff M, Nagarwalla N. Spatial disease clusters: detection and inference. Stat Med. 1995;14:799-810.

28. Lobato-Cordero A, Quentin E, Lobato-Cordero G. Spatiotemporal analysis of influenza morbidity and its association with climatic and housing conditions in Ecuador. J Environ Public Health. 2019;2019:6741202.

29. Zhang Y, Wang X, Li Y, Ma J. Spatiotemporal analysis of influenza in China, 2005-2018. Sci Rep. 2019;9:19650.

30. Santos Junior CJ, Costa PJ, Silva JV, Souza AK, Silva JP, Rocha TJ. Tecnologias digitais e de geoprocessamento aplicadas ao monitoramento da doença de coronovírus 2019 (COVID-19). Hygeia. 2020;Ed Esp COVID-19:1-10.

31. Minas Gerais. Secretaria de Estado de Saúde. Boletim epidemiológico e assistencial COVID-19: edição especial, número 11. [cited 2021 Feb 20]. Available from: http:// coronavirus.saude.mg.gov.br/images/boletim/07-julho/01-07_ Boletim_Edicao-Especial-N11.pdf

32. Ribeiro SP, Castro e Silva A, Dáttilo W, Reis AB, Góes-Neto A, Alcantara L, et al. Severe airport sanitarian control could slow down the spreading od COVID-19 pandemics in Brazil. PeerJ. 2020;8:e9446

33. Alves TE, Souza TA, Silva SA, Ramos NA, de Oliveira SV. Underreporting of death by COVID-19 in Brazil's second most populous state. Front Public Health. 2020;8:578645.

34. Falcão JL, Rabelo DR, Falcão SN, Pereira Neto JA, Arnauld FC, Belém LS, et al. Impact of social isolation during COVID-19 pandemic on arrivals at emergency department 
and on percutaneous coronary intervention for myocardial infarction at a cardiology hospital. J Transcat Intervent. 2020;28:eA20200009.

35. Garcia LP, Duarte E. Nonpharmaceutical interventions for tackling the COVID-19 epidemic in Brazil. Epidemiol Serv Saude. 2020;29:e2020222.

36. Silva JH, Oliveira EC, Hattori TY, Lemos ER, Terças-Trettel AC. Description of COVID-19 cluster: isolation and testing in asymptomatic individuals as strategies to prevent local dissemination in Mato Grosso state, Brazil, 2020. Epidemiol Serv Saude. 2020;29:e2020264.

37. Smith BJ, Lim MH. How the COVID-19 pandemic is focusing attention on loneliness and social isolation. Public Health Res Pract. 2020;30:3022008.

38. Wilder-Smith A, Freedman DO. Isolation, quarantine, social distancing and community containment: pivotal role for old- style public health measures in the novel coronavirus (2019nCoV) outbreak. J Travel Med. 2020;27:taaa020.

39. Companhia Vale do Rio Doce. Na obra: informativo das obras do Projeto de Descaracterização de Barragens e adutoras - MG: testagem para COVID-19: uma ação que pode salvar vidas. [cited 2021 Feb 20]. Available from: http://www.vale.com/ brasil/PT/Documents/arquivos_links/Na-Obra_Junho_2020. pdf

40. Martines MR, Ferreira RV, Toppa RH, Assunção L, Desjardins MR, Delmelle EM. Detecting space-time clusters of COVID-19 in Brazil: mortality, inequality, socioeconomic vulnerability, and the relative risk of the disease in Brazilian municipalities. MedRxiv. In Press 2020. [cited 2021 Feb 20]. Available from: https://www.medrxiv.org/ content/10.1101/2020.06.14.20131102v1 